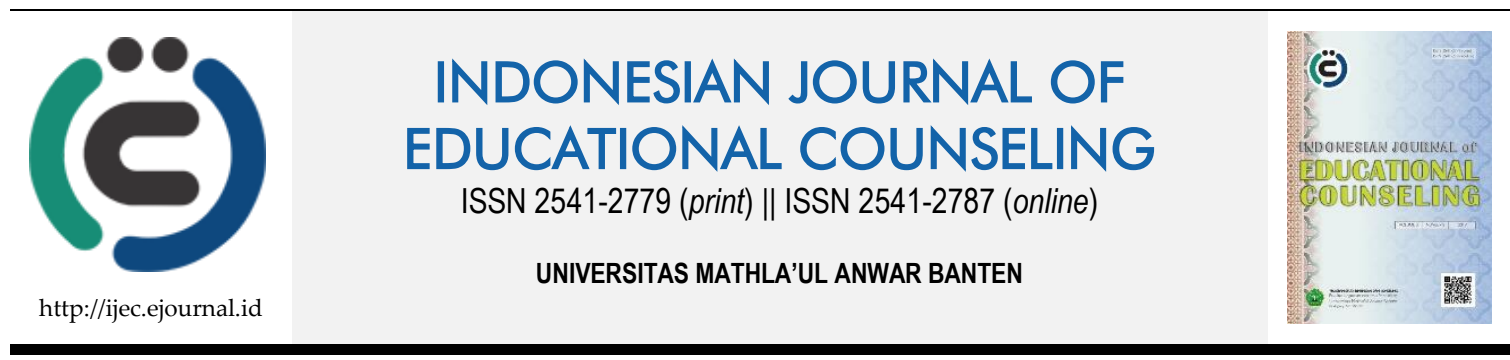

Research Based Article

\title{
Peran Regulasi Emosi dan Perhatian Orang Tua pada Social Problem-Solving Remaja yang Bersekolah Asrama
}

Arifatul Bahirah ${ }^{1}$, Rin Widya Agustin², Rini Setyowati ${ }^{3}$, Tukhas Shilul Imaroh ${ }^{4}$

1, 2,3 Universitas Sebelas Maret (UNS), Surakarta, ${ }^{4}$ Universitas Mercu Buana

\begin{tabular}{|c|c|}
\hline Article History & ABSTRACT \\
\hline $\begin{array}{l}\text { Received: } 30.04 .2019 \\
\text { Received in revised form: } \\
01.06 .2019 \\
\text { Accepted: } 02.07 .2019 \\
\text { Available online: } 24.07 .2019\end{array}$ & $\begin{array}{l}\text { THE ROLE OF EMOTION REGULATION AND PARENTAL ATTENTION } \\
\text { ON SOCIAL PROBLEM-SOLVING OF BOARDING SCHOOL'S } \\
\text { ADOLESCENT. This study aimed to know the correlation of emotion } \\
\text { regulation and parental attention to social problem solving of boarding school } \\
\text { adolescents. The research subjects were } 65 \text { students of SMAN CMBBS who were } \\
\text { selected by simple random sampling method. The instruments used are social } \\
\text { problem-solving scale, emotion regulation scale, and parental attention scale. } \\
\text { Data were analyzed by multiple regression analysis. The results showed that } \\
\text { there was a significant correlation between emotion regulation and parental } \\
\text { attention with social problem solving for SMAN CMBBS adolescents, with } \mathrm{p}= \\
0.00(\mathrm{R}=0.699) \text {. Partial correlation test proves that there is a significant } \\
\text { correlation between emotional regulation and social problem solving for } \\
\text { SMAN CMBBS adolescents }(\mathrm{p}=0.00 ; \mathrm{r} 1 \mathrm{y}=0.549) \text {. Partial correlation also } \\
\text { proves that there is a significant relationship of parental attention to social } \\
\text { problem solving for adolescent CMBBS }(\mathrm{p}=0.032 ; \mathrm{rx} 2 \mathrm{y}=0.268 \text { ). This study } \\
\text { concludes that there is a significant correlation between emotion regulation and } \\
\text { parental attention to social problem solving of SMAN CMBBS adolescents. }\end{array}$ \\
\hline
\end{tabular}

KEYWORDS: Emotion Regulation, Parental Attention, Social Problem-Solving.

DOI: $10.30653 / 001.201932 .88$

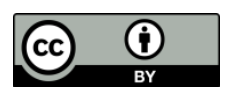

This is an open access article distributed under the terms of the Creative Commons Attribution 4.0 International License, which permits unrestricted use, distribution, and reproduction in any medium, provided the original work is properly cited. ○ 2019 Arifatul Bahirah, Rin Widya Agustin, Rini Setyowati, Tukhas Shilul Imaroh.

\section{PENDAHULUAN}

Remaja sebagai suatu periode transisi dalam rentang kehidupan manusia yang menjembatani masa kanak-kanak dengan masa dewasa merupakan individu yang selalu memuat fenomena khas yang menarik untuk dikaji. Selama periode transisi ini, remaja dihadapkan pada berbagai tuntutan dan kebutuhan sebagai individu yang bersiap untuk terlepas dari masa kanak-kanak sekaligus mempersiapkan kedewasaan, terutama dalam aspek sosial dan personal (Santrock, 2012). Papalia, Olds, dan Feldman (2009) mengatakan bahwa teman sebaya dapat berperan sebagai situasi untuk belajar mencapai kemandirian dari orang tua, dan sebagai latihan untuk membangun hubungan yang mendalam pada 
masa dewasa. Kondisi dan latihan tersebut akan dengan mudah ditemukan remaja di lingkungan sekolah, terutama sekolah yang berbasis boarding school.

SMAN Cahaya Madani Banten Boarding School (CMBBS) merupakan salah satu sekolah dengan sistem boarding school. Jumlah siswa yang diterima di sekolah ini hanya dibatasi dengan kuota 100 orang setiap tahunnya dan diharuskan menetap di asrama yang telah disediakan. Pihak sekolah juga mewajibkan siswa-siswinya untuk menjadi pengurus organisasi dan panitia agenda-agenda besar yang ada di sekolah. Berbagai situasi sosial yang ditawarkan sekolah SMAN CMBBS memungkinkan peserta didiknya untuk dapat mengembangkan kompetensi sosial dengan lebih mudah.

Beragam manfaat sekolah berbasis boarding school yang mengusung konsep "hidup bersama" memang dapat mempermudah remaja untuk dapat mengembangkan kompetensi sosial. Meskipun demikian, perlu diingat bahwa keberhasilan pengembangan kompetensi itu sendiri dipengaruhi oleh seberapa baik remaja dapat menyelesaikan konflik-konflik sosial. Beberapa konflik sosial yang biasa ditemui oleh remaja di sekolah boarding school berkisar pada konflik dengan teman sekamar, teman satu organisasi, maupun dengan kakak atau adik kelas di sekolah.

SMAN CMBBS sebagai salah satu SMA unggulan di Provinsi Banten memiliki iklim akademik yang tinggi. Sekolah memberikan tuntutan pada peserta didiknya untuk mencapai standar prestasi belajar yang tinggi. Kurikulum dan muatan mata pelajaran yang diajarkan di sekolah disetarakan dengan standar olimpiade nasional maupun internasional. Tuntutan ini seakan menambah tantangan bagi remaja bahwa mereka diharuskan untuk belajar lebih keras dibandingkan remaja SMA lainnya untuk dapat mencapai standar prestasi belajar yang telah ditetapkan sekolah, sehingga kadangkala hal ini mempengaruhi kehidupan sosialnya. Oleh karena itu, situasi dilematis antara kehidupan sosial dan tuntutan akademik ini mengindikasikan bahwa remaja SMAN CMBBS membutuhkan suatu keterampilan sosial yang cukup untuk dapat menyelaraskan kehidupan sosial dengan akademisnya, yaitu dengan membekali diri dengan keterampilan penyelesaian masalah sosial (Social Problem-Solving).

Tuntutan remaja dalam menyelesaikan masalah sekaligus mempertahankan relasi sosial dengan teman sebayanya membuat Social Problem-Solving yang dilakukan haruslah hati-hati. Sebab pada masanya, remaja cenderung memiliki emosi yang bergejolak. Hal ini membuat remaja kesulitan mengatasi tekanan emosi negatif sehingga cenderung untuk mengikuti emosinya ketika bertindak ataupun mengambil keputusan. Oleh karena itu, dalam prakteknya, keterampilan Social Problem-Solving seseorang haruslah diiringi dengan kemampuan mengelola emosi agar individu dapat menjaga kualitas relasi sosialnya. Hal ini sejalan dengan hasil studi Widanti, Hardjajani, dan Karyanta (2015) yang membuktikan bahwa terdapat hubungan yang positif antara kestabilan emosi dengan problem solving mahasiswa psikologi Universitas Sebelas Maret Surakarta. Kemampuan mengelola emosi ini selanjutnya disebut dengan regulasi emosi.

Keterampilan dalam bersosialisasi maupun menyelesaikan masalah tidak begitu saja secara instan ada dalam diri seorang remaja. Dalam melewati masa-masanya, remaja pada hakikatnya tetaplah seorang anak, membutuhkan kasih sayang orang tua, butuh dipahami, didengarkan keluh kesahnya, serta diberikan arahan dan bimbingan dalam menghadapi masalahnya. Hal inilah yang kemudian terpenuhi melalui perhatian orang tua. Temuan penelitian Mahanani (2015) menyatakan bahwa anak yang kurang mendapat 
perhatian atau bahkan diacuhkan oleh orang tua akan berlaku yang kurang wajar dengan maksud untuk memperoleh perhatian. Sedangkan anak yang mendapat perhatian yang berlebihan dari orang tuanya justru membuat anak sangat tergantung pada orang tua, sehingga menjadikan anak kurang mandiri dengan kehidupannya.

Dengan demikian, regulasi emosi bersama-sama dengan perhatian orang tua diharapkan dapat menjadi solusi untuk membantu Social Problem-Solving pada remaja boarding school, khususnya remaja SMAN CMBBS. Penelitian ini berangkat dengan tiga hipotesis, yaitu (1) Terdapat hubungan positif antara regulasi emosi dan perhatian orang tua dengan Social Problem-Solving remaja SMAN CMBBS, (2) Terdapat hubungan positif antara regulasi emosi dengan Social Problem-Solving remaja SMA CMBBS, dan (3) Terdapat hubungan positif antara perhatian orang tua dengan Social Problem-Solving remaja SMA CMBBS.

\section{Social Problem-Solving}

D'Zurilla, Nezu, dan Maydeu-Olivares (2004) mendefinisikan problem solving sebagai proses kognitif maupun perilaku yang dilakukan oleh seorang individu, pasangan, atau kelompok untuk mengidentifikasi atau menemukan solusi yang efektif dalam masalah tertentu yang dihadapi dalam kehidupan sehari-hari. Sedangkan secara lebih khusus, D'Zurilla dan Nezu (1982) menekankan bahwa istilah Social Problem-Solving merujuk pada proses penyelesaian masalah yang terjadi di lingkungan alamiah atau di dunia nyata. Pernyataan lebih rinci tentang Social Problem-Solving dikemukakan oleh D'Zurilla, Nezu, dan Maydeu-Olivares (2004) bahwasanya lingkup sosial yang dimaksud Social ProblemSolving sendiri tidak terbatas pada penyelesaian masalah jenis tertentu saja, melainkan semua jenis masalah yang mempengaruhi fungsi adaptif seseorang pada lingkungan sosial di dunia nyata, termasuk masalah impersonal, intrapersonal, interpersonal, sampai dengan masalah yang menyangkut masalah sosial masyarakat luas.

Konsep Social Problem-Solving menurut D'Zurilla, Nezu, dan Maydeu-Olivares (2004) terdiri dari aspek-aspek multidimensi yang saling terkait, yakni problem orientation dan problem solving style. Problem Orientation seorang individu dalam menyelesaikan masalah terbagi menjadi dua jenis, positive problem orientation dan negative problem orientation. Sedangkan Problem-Solving Styles individu terbagi menjadi tiga jenis, yakni rational problem solving style, impulsivity-carelessness style, dan avoidance style. Penelitian ini akan mengacu pada aspek Social Problem-Solving yang memfasilitasi constructive Social Problem-Solving, yakni Positive Problem Orientation (PPO) dan Rational Problem Solving-styles (RPS).

\section{Regulasi Emosi}

Gross dan Thompson (2007) mendefinisikan regulasi emosi sebagai serangkaian proses heterogen dimana emosi-emosi yang ada diatur, yang mana prosesnya dapat terjadi secara otomatis atau dikendalikan, sadar atau tidak sadar, dan akan memiliki efek pada satu titik atau lebih pada proses bagaimana emosi dihasilkan. Lebih lanjut, Thompson (2007) sendiri mengemukakan bahwa regulasi emosi menggambarkan kemampuan individu untuk memonitor, mengevaluasi, dan memodifikasi reaksi emosi yang intensif untuk mencapai suatu tujuan.

Penelitian ini mengacu padaa aspek-aspek regulasi emosi menurut Gross (2007) yang meliputi mampu mengatur emosi dengan baik, mampu mengendalikan emosi secara sadar, dengan sedikit tenaga, dan otomatis, serta mampu menguasai tekanan stres dari masalah yang dihadapi. 


\section{Perhatian Orang Tua}

Ahmadi dan Supriyono (2013) mendefinisikan perhatian sebagai konsentrasi atau aktivitas jiwa terhadap pengamatan dan pengertian dengan mengesampingkan yang lain. Ahmadi juga menjelaskan, bahwa perhatian meliputi keaktifan jiwa yang diarahkan kepada suatu objek, baik di dalam ataupun di luar dirinya. Ahmadi dan Sholeh (2005) memaparkan bahwa diantara bentuk perhatian orang tua ialah memenuhi kebutuhan anak, mulai dari kebutuhan yang bersifat fisiologis, sampai dengan kebutuhan yang sifatnya batiniyah (psikologis). Mansur (2005) mengemukakan, perhatian orang tua lebih lanjut tidak hanya sebatas memenuhi kebutuhan anak saja, melainkan senantiasa memberikan arahan dan bimbingan pada anak-anak, sejak dari pengenalan nilai dalam keluarga, hingga mengawal anak dalam kegiatan bermasyarakat.

Definisi perhatian orang tua yang akan digunakan pada penelitian ini ialah rangkaian konsep dari berbagai pendapat ahli yang telah dijelaskan sebelumnya, yakni pemusatan jiwa orang tua yang tertuju pada anak, yang meliputi pemenuhan kebutuhan anak secara fisiologis dan psikologis, serta memberikan arahan dan bimbingan pada anak, sejak dari pengenalan nilai dalam keluarga, sampai dengan mempersiapkan dan mengawal anak dalam kegiatan bermasyarakat dalam lingkup yang lebih luas.

Adapun aspek-aspek perhatian orang tua yang akan digunakan pada penelitan ini merujuk pada Ahmadi dan Sholeh (2005) serta Mansur (2005), bahwasanya aspek perhatian orang tua meliputi (1) pemenuhan kebutuhan anak, yang meliputi kebutuhan fisiologis, keselamatan dan keamanan, kepemilikan dan sosial, penghargaan diri, dan kebutuhan aktualisasi diri, serta (2) pemberian arahan dan bimbingan pada anak, termasuk di dalamnya membantu anak dalam memahami posisi dan peranannya, mengenalkan dan memberi pemahaman kepada anak tentang nilai-nilai yang ada di masyarakat, mendorong anak untuk mencari ilmu, mempersiapkan dan membantu anak saat memasuki kegiatan bermasyarakat, dan memberi kesempatan pada anak untuk berpartisipasi melakukan kegiatan keagamaan sendiri serta memberikan dukungan penuh pada anak.

\section{METODE}

Penelitian ini menggunakan pendekatan kuantitatif yang bertujuan untuk mengetahui hubungan antara regulasi emosi dan perhatian orang tua dengan Social Problem-Solving remaja SMAN CMBBS. Populasi dalam penelitian ini yaitu seluruh siswa SMAN CMBBS kelas X dan XI yang berjumlah 182 siswa. Adapun jumlah sampel pada penelitian ini ditentukan dengan menggunakan rumus slovin dan didapatkan sampel sebanyak 65 orang. Teknik pengambilan sampel yang digunakan yaitu probability sampling dengan metode simple random sampling.

Teknik pengumpulan data pada penelitian ini dilakukan dengan memberikan skala psikologi yang terdiri dari tiga macam skala, yakni skala Social Problem-Solving $(\mathrm{r}=0,913)$, regulasi emosi $(0,915)$, dan perhatian orang tua $(r=0,892)$. Adapun teknik analisis data yang digunakan pada penelitian ini yaitu analisis regresi berganda untuk menguji hipotesis satu, dan analisis korelasi untuk menguji hipotesis dua dan tiga. Keseluruhan data akan diolah dan diuji dengan menggunakan bantuan program Statistical Product and Service Solution (SPSS) versi 23.0. 


\section{HASIL DAN PEMBAHASAN}

Uji hipotesis pada penelitian ini dilakukan dengan analisis regresi berganda (Multiple Regression Analysis) yang dilakukan dengan dua tahapan, yaitu uji simultan $\mathrm{F}$ dan uji korelasi parsial.

Tabel 1. Hasil Uji Simultan

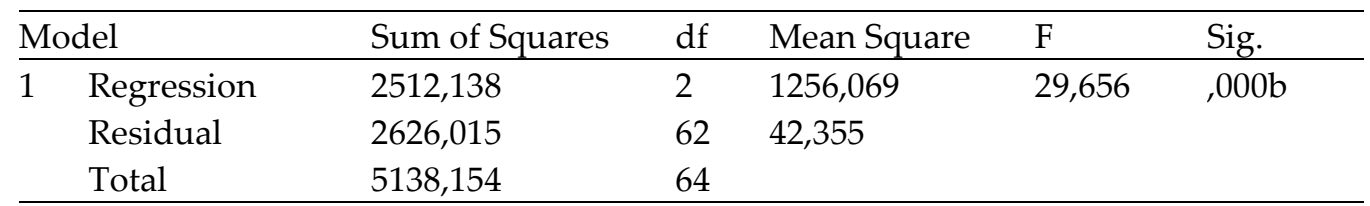

a. Dependent Variable: SPS

b. Predictors: (Constant), POT, Reg.Emosi

Hasil uji simultan diperoleh nilai Fhitung sebesar 29,656 dengan $p$-value yang dapat dilihat pada kolom Sig. sebesar 0,000. Hasil nilai F yang didapatkan sebesar 29,656 >3,13

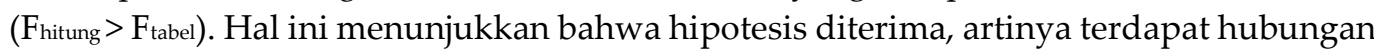
signifikan antara regulasi emosi dan perhatian orang tua dengan Social Problem-Solving remaja SMAN CMBBS.

Tabel 2. Hasil Analisis Nilai Koefisien Korelasi Ganda

\begin{tabular}{lllll}
\hline Model & $\mathrm{R}$ & $\mathrm{R}$ Square & Adjusted R Square & Std. Error of the Estimate \\
\hline 1 &, $699 \mathrm{a}$ &, 489 &, 472 & 6,508 \\
\hline
\end{tabular}

a. Predictors: (Constant), POT, Reg.Emosi

b. Dependent Variable: SPS

Berdasarkan tabel diketahui jika nilai $\mathrm{R}=0,699$ yang mengindikasikan bahwa terdapat hubungan yang kuat antara regulasi emosi dan perhatian orang tua dengan Social Problem-Solving remaja SMAN CMBBS. Selain itu, didapatkan nilai $\mathrm{R}$ square sebesar 0,489 atau $48,9 \%$ yang menunjukkan prosentase sumbangan variabel regulasi emosi dan perhatian orang tua keduanya secara bersama-sama berhubungan terhadap Social Problem-Solving.

Hasil uji korelasi parsial variabel regulasi emosi dengan Social Problem-Solving menunjukkan signifikansi 0,000 ( $<<0,05)$. Hal ini menunjukkan bahwa terdapat korelasi yang signifikan dan hubungan positif antara regulasi emosi dengan Social Problem-Solving remaja SMA CMBBS. Selain itu, hasil uji korelasi parsial variabel perhatian orang tua dan Social Problem-Solving menunjukkan signifikansi $0,032(\mathrm{p}<0,05)$. Hal ini menunjukkan bahwa terdapat korelasi signifikan dan hubungan positif antara perhatian orang tua dengan Social Problem-Solving.

Tinggi-rendahnya kemampuan Social Problem-Solving seseorang dapat dipengaruhi oleh dua faktor, yakni faktor internal maupun eksternal. Beberapa faktor internal dari dalam diri individu yang dapat mempengaruhi kemampuan Social Problem-Solving diantaranya meliputi perasaan-perasaan yang timbul dari kepribadian individu, baik orientasi individu dalam melihat masalah (problem orientation) maupun gaya individu dalam menyelesaikan masalah sosialnya (problem-solving style). Rich dan Bonner (2004) menyebutkan bahwa salah satu diantara perasaan negatif yang dapat mempengaruhi Social Problem-Solving seseorang yaitu kecemasan individu dalam memenuhi harapan 
sosial. Semakin tinggi kecemasan seseorang dalam memenuhi harapan sosial, maka semakin rendah kecenderungannya dalam menggunakan positive problem orientation dan rational problem-solving style.

Perasaan-perasaan negatif yang dialami seorang individu dapat berdampak terhadap Social Problem-Solving. Salah satu hal yang bisa dilakukan untuk meminimalisir dampaknya yaitu dengan meningkatkan kemampuan seseorang dalam mengelola emosi. Pada remaja yang bersekolah di boarding school, mengelola emosi dapat dilakukan melalui kelekatan dengan teman sebaya (peer attachment). Apabila remaja memiliki peer attachment yang baik, remaja akan mampu mengkomunikasikan emosi negatif yang ia rasakan secara terbuka. Ketika individu dapat mengutarakan perasaan dan masalah yang dialami, kemudian mendapatkan nasihat untuk mengatasinya, remaja boarding school akan memiliki emosi yang lebih stabil sehingga dapat berpikir jernih untuk memikirkan solusi efektif dalam menyelesaikan masalah. Hasil penelitian Rasyid (2012) menyatakan bahwa terdapat hubungan positif antara peer attachment dengan regulasi emosi remaja SMAN 10 Samarinda Boarding School.

Regulasi emosi yang baik dicapai oleh individu ketika mampu mengatasi tekanan emosi negatif, sehingga kondisi ini memungkinkan individu menyelesaikan masalah sosial dengan konstruktif. Hasil penelitian ini membuktikan bahwa regulasi emosi memiliki hubungan positif dan signifikan dalam mempengaruhi Social Problem-Solving remaja SMA CMBBS dengan nilai korelasi 0,549 dan sumbangan efektif sebesar 36,86\%. Temuan penelitian ini sejalan dengan penelitian Lougheed dan Hollenstein (2012) yang menunjukkan bahwa regulasi emosi berhubungan dengan bagaimana remaja menginternalisasi masalahnya. Semakin tinggi regulasi emosi seseorang, semakin tinggi pula probabilitas individu tersebut untuk menyelesaikan masalah secara konstruktif. Temuan penelitian ini pun sejalan dengan temuan Widanti, Hardjajani, dan Karyanta (2015) yang membuktikan bahwa terdapat hubungan yang positif antara kestabilan emosi dengan problem solving.

Selain faktor internal emosi, Rich dan Bonner (2004) juga memasukkan faktor pengalaman masa kanak-kanak sebagai faktor biopsikososial yang turut mempengaruhi Social Problem-Solving individu. Lingkungan interpersonal awal yang telah dikenal anak akan menjadi pondasi kemampuan anak dalam menyelesaikan masalah di lingkungan sosialnya. Tidak hanya itu saja, temuan penelitian ini membuktikan bahwasanya perhatian orang tua yang diberikan juga turut memberikan kontribusi bagi tinggi rendahnya kemampuan Social Problem-Solving seorang anak meskipun telah menginjak usia remaja.

Hasil penelitian ini membuktikan bahwa perhatian orang tua memiliki hubungan positif dan signifikan dalam mempengaruhi Social Problem-Solving pada remaja SMAN CMBBS dengan nilai korelasi 0,268 dan sumbangan efektif $12,04 \%$. Perhatian orang tua berkontribusi dalam tercukupi atau tidaknya pemenuhan afeksi seorang anak. Apabila perhatian orang tua mencukupi kebutuhan afeksi anak, maka anak akan cenderung mengembangkan perasaan dan kerangka pemikiran yang positif pada dunianya, tidak terkecuali dunia sosial. Selanjutnya, perasaan dan kerangka pemikiran yang positif berkontribusi pada keterampilan Social Problem-Solving anak, baik orientasi anak terhadap masalah, maupun style anak dalam menyelesaikan masalah. 
Sumbangan efektif perhatian orang tua pada Social Problem-Solving remaja SMA boarding school tidak terlalu tinggi oleh karena pada masa remaja, terjadi perubahan dominasi orientasi sosial kepada teman sebaya sebagai situasi untuk belajar mencapai kemandirian dari orang tua. Terlebih lagi, sekolah dengan sistem boarding school menciptakan iklim yang mendukung remaja untuk belajar membuat keputusan sendiri dan bertanggung jawab pada dirinya sendiri. Mekipun demikian, hal ini tidak berarti arahan dan bimbingan orang tua tidak diperlukan ataupun tergantikan dengan arahan dan bimbingan dari teman sebaya. Perhatian orang tua tetap dibutuhkan oleh remaja, hanya saja kadar intensitas arahan dan bimbingannya tidak sekuat pada masa kanakkanak.

Temuan penelitian ini sekaligus memperkuat penelitian Hyoscyamina (2011) yang menyatakan bahwa peran orang tua, seperti figur, pengasuhan, dan intensitas interaksi sehari-hari antara orang tua dengan anak berkontribusi menanamkan orientasi karakter anak terhadap masalah sehari-hari dan membekali anak keterampilan untuk menyelesaikan masalah. Hasil penelitian ini juga mendukung temuan Cavanaugh dan Buehler (2016) yang menyatakan bahwa dukungan orang tua dan teman sebaya berhubungan dengan menurunkan tingkat kesepian dan kecemasan sosial pada remaja sehingga remaja dapat menyelesaikan masalah sosial dengan lebih baik. Dengan demikian, temuan penelitian ini menunjukkan bahwa regulasi emosi bersama-sama dengan perhatian orang tua berperan positif dan signifikan dalam mempengaruhi Social Problem-Solving remaja SMA boarding school.

\section{SIMPULAN}

Penelitian ini ditujukan untuk mengetahui hubungan antara regulasi emosi dan perhatian orang tua dengan Social Problem-Solving pada remaja boarding school, khususnya remaja SMA CMBBS. Hasil penelitian menunjukkan bahwa terdapat hubungan positif dan signifikan antara regulasi emosi dan perhatian orang tua dengan Social ProblemSolving remaja SMAN CMBBS. Hal ini berarti semakin tinggi regulasi emosi dan perhatian orang tua yang dimiliki, maka semakin tinggi pula kemampuan Social Problem-Solving remaja SMAN CMBBS. Adapun saran yang dapat diberikan oleh peneliti melalui hasil penelitian ini dantaranya yaitu: (1) Untuk sekolah boarding school diharapkan untuk dapat mempertahankan dan meningkatkan keterampilan Social Problem-Solving peserta didiknya. Beberapa hal diantaranya yang dapat dilakukan yakni dengan mengadakan pembinaan atau program pengembangan pengelolaan emosi bagi peserta didiknya (2) Untuk kalangan akademisi diharapkan penelitian ini dapat menjadi referensi sekaligus stimulasi untuk ke depannya dilakukan penelitian-penelitian lanjutan terhadap remaja di sekolah boarding school, baik dengan lingkup tema penelitian yang sama, maupun berlainan.

\section{REFERENSI}

Ahmadi, A. \& Sholeh, M. (2005). Psikologi perkembangan. Jakarta: Rineka Cipta.

Ahmadi, A. \& Supriyono, W. (2013). Psikologi belajar. Edisi Revisi. Jakarta: Rineka Cipta. 
Cavanaugh, A.M. \& Buehler, C. (2016). Adolescent loneliness and social anxiety: The role of multiple sources of support. Journal of Social and Personal Relationship, 33(2), 149170.

D'Zurilla, T. J., \& Nezu, A. M.. (1982). Social problem-solving in adults. In P. C. Kendal (Ed), Advances in cognitive-behavioral research and therapy (pp. 201-274). New York: Academic Press.

D'Zurilla, T. J., Nezu, A. M., \& Maydeu-Olivares, A. (2004). Social problem-solving: Theory and assessment. In E. C. Chang, T. J. D'Zurilla, \& L. J. Sanna (Eds.), Social problem-solving: Theory, research, and training (pp. 11-27). Washington: American Psychological Association.

Gross, J. J. (2007). Handbook of emotion regulation. New York: The Guillford Press.

Gross, J. J., \& Thompson, R. A. (2007). Emotion regulation: Conceptual Foundations. In J. J Gross (Ed.), Handbook of emotion regulation (pp. 3-24). New York: The Guillford Press.

Hyoscyamina, D. E. (2011). Peran keluarga dalam membangun karakter anak. Jurnal Psikologi, 10(2), 144-152.

Lougheed, J. P., \& Hollenstein, T. (2012). A limited repertoire of emotion regulation strategies is associated with internalizing problems in adolescence. International Journal of Social Development, 21(4), 704-721.

Maharani, M. (2015). Hubungan perhatian orangtua dengan perkembangan sosial anak usia 4-5 tahun di desa birit kecamatan wedi kabupaten Klaten tahun 2015. Naskah Publikasi Fakultas Ilmu Pendidikan Universitas Negeri Yogyakarta. Yogyakarta: UNY.

Mansur. (2005). Pendidikan Anak Usia Dini dalam Islam. Yogyakarta: Pustaka Pelajar.

Papalia, D. E., Olds, S.W., \& Feldman, R.D. (2009). Human Development (10th ed.). New York: McGraw-Hill.

Rich, A.R., \& Bonner, R.L. (2004). Mediators and moderators of social problem-solving. In E. C. Chang, T. J. D'Zurilla, \& L. J. Sanna (Eds.), Social problem-solving: Theory, research, and training (pp. 28-45). Washington: American Psychological Association.

Santrock, J. W. (2012). Life-span development: perkembangan masa hidup, (13th ed). Jakarta: Erlangga.

Slameto. (2010). Belajar dan faktor-faktor yang mempengaruhinya. Jakarta: Rineka Cipta.

Widanti, M. C., Hardjajani, T., \& Karyanta N. A. (2015). Hubungan antara kestabilan emosi dengan problem solving pada mahasiswa program studi psikologi Universitas Sebelas Maret Surakarta. Jurnal Ilmiah Psikologi Candrajiwa, 4(2), 121-132. 